\begin{tabular}{c|c|c}
\hline \hline & MARINE ECOLOGY PROGRESS SERIES \\
Mol. 215: 307-310, 2001 & $\begin{array}{c}\text { Mar Ecol Prog Ser } \\
\text { Published May } 31\end{array}$ \\
\hline
\end{tabular}

\title{
COMMENT
}

\section{The stony road to reliable filtration rate measurements in bivalves: a reply}

\author{
Hans Ulrik Riisgård*
}

Research Centre for Aquatic Biology (Odense University), Hindsholmvej 11, 5300 Kerteminde, Denmark

Evaluating the 'reliability' of filtration rate measurements in bivalves is troublesome. It is true as stated by Cranford (2001) that filtration rate measurements require close attention to the potential negative effects of experimental conditions. It is important to measure the actual filtration rates in the field with in situ methods, which should be reliable, i.e. verified against another (more reliable) method under controlled conditions in the laboratory. It would be interesting to see results of such calibrations and also to find an explanation of why filtration rates of bivalves in some cases may be quite different when feeding on a diet of natural seston rather than on a 'laboratory diet' of algal cells.

My examination of available data on filtration rates in bivalves showed that most laboratory methods agree well when the necessary prerequisites are fulfilled (Riisgård 2001a). But it remains a matter of discussion whether the filtration rate is 'physiologically regulated' (Bayne 1993, 1998, Cranford \& Hill 1999, Hawkins et al. 1999) or whether it should be conceived as a 'basically autonomous process' (Jørgensen 1990, 1996, Riisgård 1991, Clausen \& Riisgård 1996, Riisgård \& Larsen 2000). Therefore, I recently wrote a follow-up paper in which I attempted to find starting points for solving the current controversy (Riisgård 2001b). I called attention to the lack of adequate definitions of what is meant by 'physiological regulation' of the filtration rate and I proposed a set of definitions, which are examined in light of bioenergetics. Against this background support was found for assuming that the filtration rate capacity may be constantly used within a certain phytoplankton concentration interval, from a 'lower

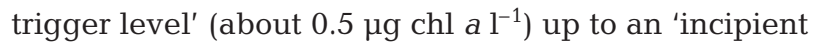

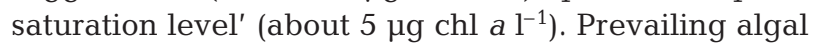
concentrations in non-eutrophicated waters lie often between 1 and $5 \mu \mathrm{g} \mathrm{chl} \mathrm{a} \mathrm{l^{-1 }}$ (Riisgård \& Larsen 2000) and it is therefore reasonable to suggest that the maxi-

\footnotetext{
*E-mail: hur@biology.sdu.dk
}

mum filtration rates listed by Riisgård (2001a, Table 1 therein) may often - or usually — be realised in nature. However, using the in situ bio-deposit method, Cranford \& Hill (1999) concluded that 'bivalves seldom utilise their full clearance potential in nature' and that laboratory measurements of filtration rates 'appear to be of limited application for predicting feeding activity in nature'. This statement appears to lack substantiation as does the recent comment by Cranford (2001) that bivalves 'more often feed at a much reduced rate' compared to the filtration capacity, 'on average 320 to $1365 \%$ higher than the in situ measurements'.

Clearly, in situ methods are needed and the biodeposit method may be a candidate, but the preconditions for use of the method should be further tested, and field studies should be supplemented with video observations of valve gape. Further, the potential problems of placing 25 large (shell length $L=77 \mathrm{~mm}$ ) mussels in a 'bivalve cage' on top of the 'new type of sediment trap' constructed for bivalve studies (Cranford \& Hill 1999, Fig. 1 \& Table 1 therein) should also be thoroughly evaluated. With a potential ability of these mussels to filter a water volume of about $25 \times 13=$ $325 \mathrm{l} \mathrm{h}^{-1}$ (using the equation for individual filtration rate $F$ as a function of shell length $L$ found for $M$. edulis by Kiørboe \& Møhlenberg [1981]: $F=0.0012 L^{2.14}=131$ $\mathrm{h}^{-1}$ ) it seems likely that only a fairly strong water current through the mussel cage would eliminate re-filtration (recirculation) and thus prevent underestimation of the true filtration rates (volume flow rates). For the solution of the related problem of re-filtration within a group of mussels in a flow-through chamber, see Riisgård \& Møhlenberg (1979, Figs. 1 \& 2 therein): clearance rate as a function of flow rate through the mussel chamber was measured, and it was found that above a certain flow rate the clearance values form a plateau where the clearance rate is representative of the filtration rate. A similar test in a controlled flume is required to evaluate the bio-deposit method. Subsequently, a current meter combined with the sediment trap may 
identify time periods during, e.g., the tidal cycle (cf. Cranford \& Hargrave 1994, their Fig. 2, Cranford et al. 1998, their Fig. 1), where the water flow rate is too slow to eliminate re-filtration in the bivalve cage - or perhaps too high, causing 'flow-induced inhibition' of the filtration rate (Wildish \& Miyares 1990, Wildish \& Saulnier 1993), and clearly, a strong current could prevent the collection of all bio-deposits. Other reasons why the in situ bio-deposit method may underestimate the 'reliable' laboratory filtration rates include closure of valves during periods with either very high algal concentrations (Fig. 1) or algal concentrations below the 'trigger level' for cessation of filter-feeding activity.

One drawback of using the in situ sediment trap is the elevated position of the bivalve cage $1.5 \mathrm{~m}$ above the sea bed where both the current-speed and algalconcentration regimes may differ from those at the sea bed (Fréchette et al. 1993, Dolmer 2000a,b). Due to grazing impact by benthic filter feeders, vertical algal concentration profiles may be pronounced up to 1-2 m above the bottom, and feeding activity in mussels elevated above the bottom does not represent the actual situation on the sea floor. When interpreting in situ data, it is necessary to distinguish between actual individual filtration rate and realised consumption or grazing by a group/population of bivalves.

Based on the above account it is difficult to accept the statement by Cranford \& Hill (1999) that 'the similarity of actual and calculated growth provides a high level of confidence in the accuracy of reported in situ clearance, ingestion and absorption rates'. The energy budget calculations referred to cannot easily be verified, but inspection of Table 1 in Cranford \& Hill (1999) shows that 'start' or 'finish' values for body dry weights for both the scallops and mussels are missing in 4 cases in the autumn sediment-trap deployments, making estimates of the actual growth impossible. In the June-July experiments, the actual growth of Mytilus edulis was negative, $-0.9 \mathrm{~g}$ dry wt over $38 \mathrm{~d}$ or about $-20 \mathrm{~J} \mathrm{~h}^{-1}$, which is about twice the metabolic energy loss $\left(9.5 \mathrm{~J} \mathrm{~h}^{-1}\right)$. Further, the 'water processing potential' for $M$. edulis (estimated as the ratio between filtration rate, $F$, and respiration rate, $R$, see Riisgård \& Larsen 2001) can be estimated to be $0.750 / 0.475=1.61$ of water pumped per $\mathrm{ml}$ of $\mathrm{O}_{2}$ consumed. This value is rather low for an obligate filter feeder according to Table 3 in Riisgård \& Larsen (2000) which shows $F / R$-values for various filter-feeding invertebrates (sponges, bryozoans, polychaetes, ascidians, etc.). In the case considered, the mean ambient phytoplankton concentration would need to be as high as

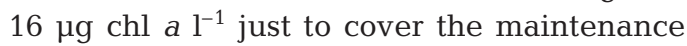
metabolic requirement of the mussels.
Obviously, there is a need for field measurements of phytoplankton concentrations in the bottom-near water close to filter-feeding bivalves combined with observations of the feeding behaviour. For different areas and different times of the year, the percentage of total time that filter-feeding bivalves exploit their filtration rate capacity could in this way be determined.

Although it is difficult to directly measure the filtration rates of bivalves in their natural environment, laboratory studies have shown that filtration rate in mussels is correlated with opening degree of the valves (e.g., Møhlenberg \& Riisgård 1979, Riisgård \& Randløv 1981, Jørgensen et al. 1988). In Mytilus edulis high algal concentrations may cause overloading of the alimentary canal and subsequently cause valve closure and reduction of the filtration rate, i.e., 'saturation reduction'. This has been demonstrated in many laboratory studies (Riisgård 1991), but recently also observed in the inner part of the heavily eutrophicated Limfjorden (Denmark) by Møhlenberg (1999), who studied the filterfeeding activity of $M$. edulis by means of underwater video. At the same time as determining the degree of valve opening by video, the concentration of chlorophyll $a$ in the near-bottom water was measured. It was found that the filter-feeding activity was dependent on the algal concentration: when the concentration ex-

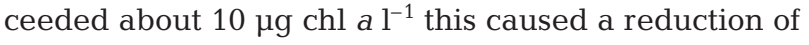
the valve gape and thus the filtration rate (Fig. 1).

Such reduction of filtration rate is presumably caused by 'pure food' in the digestive system, not inorganic silt. Even relatively high concentrations of silt or resuspended bottom material (up to $20 \mathrm{mg} \mathrm{l}^{-1}$ ) have no effect on the filtration rate because the mussels are able, by means of their labial palps, to efficiently reject inorganic particles as pseudofaeces (Kiørboe \& Møhlenberg 1981, see also Kiørboe et al. 1980).

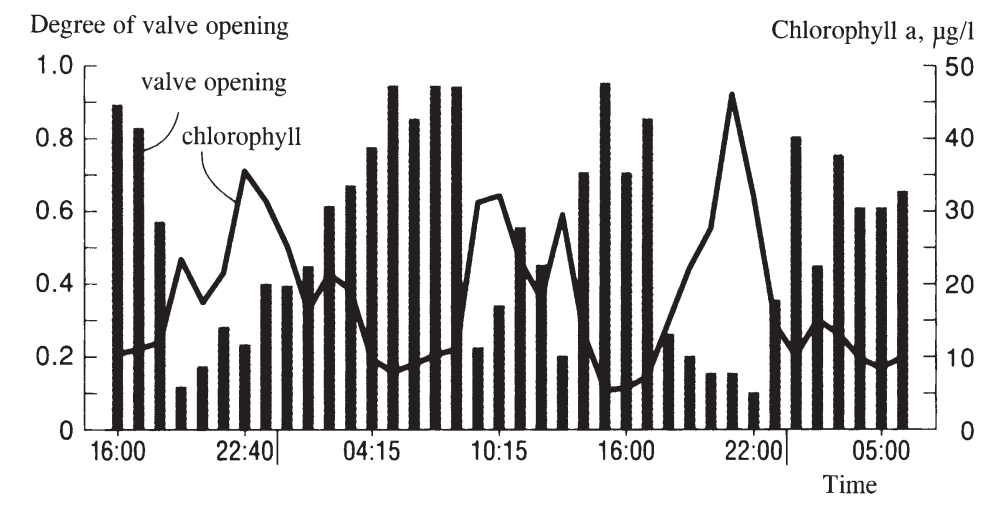

Fig. 1. Mytilus edulis. Filter-feeding activity, expressed as degree of valve opening $(1.0=$ maximum valve opening $)$, in a natural population of mussels in the eutrophicated Limfjorden (Denmark) and nearbottom concentration of chlorophyll $a$. It is seen that chlorophyll a concentrations higher than about $10 \mathrm{\mu g} \mathrm{l}^{-1}$ cause reduced valve opening. Adapted from Møhlenberg (1999) 
Although more field studies along the above lines are needed, it seems reasonable for the time being to suggest that Mytilus edulis and other bivalves may constantly exploit their filtration capacity in the concentration interval from the lower trigger level up to

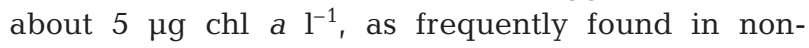
eutrophicated waters. Like in other ciliary filterfeeding invertebrates (Riisgård \& Larsen 1995, 2001), the filtration process in bivalves may be conceived as basically autonomous in the lower end of the prevailing range of natural phytoplankton and silt concentrations.

No data obtained by means of the 'flow-through chamber method' are included in the list of 'reliable' filtration rates measured by means of different methods under optimal laboratory conditions (Riisgård 2001a, Table 1 therein). Erroneous use of this method (see also Riisgård 1977, 2001b) has resulted in many incorrect values of filtration rates. The reason for not including a number of other data in the same table is explained in the following. Filtration rates in the scallop Placopecten magellanicus have been determined both in the laboratory and in nature (MacDonald \& Thompson 1986, Cranford \& Grant 1990, Grant \& Cranford 1991, Cranford \& Gordon 1992), but — as also pointed out by Jørgensen (1996) - the results are not easily reconciled and it is still unclear why a number of experiments have resulted in low filtration rates of natural seston. The rate at which $P$. magellanicus filtered suspensions of cultured algae agreed fairly well with rates measured in 2 other pectinids, Argopecten irradians (Riisgård 1988) and Chlamys hastata (Meyhöfer 1985, Bernard \& Noakes 1990). C. hastata filtered natural sea water at the rate of $8.7 \mathrm{l} \mathrm{h}^{-1} \mathrm{~g}^{-1}$, as measured with a thermistor flowmeter by Meyhöfer (1985). Compared to this rate, the filtration rates reported for $P$. magellanicus by MacDonald \& Thompson (1986) using the flow-through chamber method (with flow rates of 80 to $300 \mathrm{ml} \mathrm{min}^{-1}$ and $\leq 30 \%$ removal of natural particles down to a diameter of $2 \mu \mathrm{m}$ ) were low, only 0.6 to $1.3 \mathrm{l} \mathrm{h}^{-1} \mathrm{~g}^{-1}$. The particles counted extended down into the range $<5$ to $7 \mu \mathrm{m}$, where efficiency of retention rapidly declines in pectinids (Møhlenberg \& Riisgård 1978, Riisgård 1988, Cranford \& Grant 1990).

In future studies, it is crucial that the method used should enable measurement of the maximum filtration rate, which should subsequently act as a reference value in longer-term studies of environmental factors. A precondition for studying possible physiological regulation of filtration rate in bivalves is the ability to make accurate and reproducible measurements. That was the main message in my MEPS 'stony road' review (Riisgård 2001a). It is satisfactory to note that at long last we are now beginning a much needed discussion of the 'reliability' of filtration rates in bivalves.
Acknowledgements. Thanks are due to Profs. Poul S. Larsen and Tom Fenchel for inspiring comments.

\section{LITERATURE CITED}

Bayne BL (1993) Feeding physiology of bivalves: time-dependent and compensation for changes in food availability. In: Dame RF (ed) Bivalve filter feeders. NATO ASI Series Vol. G 33. Springer-Verlag, Heidelberg, p 1-24

Bayne BL (1998) The physiology of suspension feeding by bivalve molluscs: an introduction to the Plymouth 'TROPHEE' workshop. J Exp Mar Biol Ecol 219:1-19

Bernard FR, Noakes DJ (1990) Pumping rates, water pressures, and oxygen use in eight species of marine bivalve molluscs from British Columbia. Can J Fish Aquat Sci 47: 1302-1306

Clausen I, Riisgård HU (1996) Growth, filtration and respiration in the mussel Mytilus edulis: no regulation of the filterpump to nutritional needs. Mar Ecol Prog Ser 141:37-45

Cranford P (2001) On evaluating the 'reliability' of filtration rate measurements in bivalves. Mar Ecol Prog Ser 215: 303-305

Cranford PJ, Gordon DC Jr (1992) The influence of dilute clay suspensions on sea scallop (Placopecten magellanicus) feeding activity and tissue growth. Neth J Sea Res 30: $107-120$

Cranford PJ, Grant J (1990) Particle clearance and absorption of phytoplankton and detritus by the sea scallop Placopecten magellanicus (Gmelin). J Exp Mar Biol Ecol 137: 105-121

Cranford PJ, Hargrave BT (1994) In situ time-series of ingestion and absorption of suspension-feeding bivalves Placopecten magellanicus. Limnol Oceanogr 39:730-738

Cranford PJ, Hill PS (1999) Seasonal variation in food utilization by the suspension-feeding bivalve molluscs Mytilus edulis and Placopecten magellanicus. Mar Ecol Prog Ser 190:223-239

Cranford PJ, Emerson CW, Hargrave BT, Miligan TG (1998) In situ feeding and absorption responses of sea scallops Placopecten magellanicus (Gmelin) to storm-induced changes in the quality and composition of the seston. J Exp Mar Biol Ecol 219:45-70

Dolmer P (2000a) Algal concentration profiles above mussel beds. J Sea Res 43:113-119

Dolmer P (2000b) Feeding activity of mussels Mytilus edulis related to near-bed currents and phytoplankton biomass. J Sea Res 44:221-231

Fréchette M, Lefaivre D, Butman CA (1993) Bivalve feeding and the benthic boundary layer. In: Dame RF (ed) Bivalve filter feeders in estuarine and coastal ecosystem processes. NATO ASI Series, Vol G 33. Springer-Verlag, Heidelberg, p 325-369

Grant J, Cranford PJ (1991) Carbon and nitrogen scope for growth as a function of diet in the sea scallop Placopecten magellanicus. J Mar Biol Assoc UK 71:437-450

Hawkins ASJ, James MR, Hickman RW, Hatton S, Weatherland $M$ (1999) Modelling of suspension-feeding and growth in the green-lipped mussel Perna canaliculus exposed to natural and experimental variations of seston availability in the Marlborough Sounds, New Zealand. Mar Ecol Prog Ser 191:217-232

Jørgensen CB (1990) Bivalve filter feeding: hydrodynamics, bioenergetics, physiology and ecology. Olsen \& Olsen, Fredensborg

Jørgensen CB (1996) Bivalve filter feeding revisited. Mar Ecol Prog Ser 142:287-302 
Jørgensen CB, Larsen PS, Møhlenberg F, Riisgård HU (1988) The bivalve pump: properties and modelling. Mar Ecol Prog Ser 45:205-216

Kiørboe T, Møhlenberg F (1981) Particle selection in suspension-feeding bivalves. Mar Ecol Prog Ser 5:291-295

Kiørboe T, Møhlenberg F, Nøhr O (1980) Feeding, particle selection and carbon absorption in Mytilus edulis in different mixtures of algae and resuspended bottom material. Ophelia 19:193-205

MacDonald BA, Thompson RJ (1986) Influence of temperature and food availability in the ecological energetics of the giant scallop Placopecten magellanicus. III. Physiological ecology, the gametogenic cycle and scope for growth. Mar Biol 93:37-48

Meyhöfer E (1985) Comparative pumping rates in suspension-feeding bivalves. Mar Biol 85:137-142

Møhlenberg F (1999) Muslinger som vandrensere. In: Lomstein BA (ed) Havmiljøet ved årtusindskiftet. Olsen \& Olsen, Fredensborg, p 30-46 (in Danish)

Møhlenberg F, Riisgård HU (1978) Efficiency of particle retention in 13 species of suspension feeding bivalves. Ophelia 17:239-246

Møhlenberg F, Riisgård HU (1979) Filtration rate, using a new indirect technique, in thirteen species of suspension-feeding bivalves. Mar Biol 54:143-148

Riisgård HU (1977) On measurements of the filtration rates of suspension feeding bivalves in a flow system. Ophelia 16: 167-173

Riisgård HU (1988) Efficiency of particle retention and filtration rate in 6 species of northeast American bivalves. Mar Ecol Prog Ser 45:217-223
Riisgård HU (1991) Filtration rate and growth in the blue mussel, Mytilus edulis Linneaus, 1758: dependence on algal concentration 10:29-35

Riisgård HU (2001a) On measurement of filtration rates in bivalves - the stony road to reliable data: review and interpretation. Mar Ecol Prog Ser 211:275-291

Riisgård HU (2001b) Physiological regulation versus autonomous filtration in filter-feeding bivalves: starting points for progress. Ophelia (in press)

Riisgård HU, Larsen PS (1995) Filder-feeding in marine macro-invertebrates: pump characteristics, modelling and energy cost. Biol Rev 70:67-106

Riisgård HU, Larsen PS (2000) Comparative ecophysiology of active zoobenthic filter feeding, essence of current knowledge. J Sea Res 44:169-193

Riisgård HU, Larsen PS (2001) Minireview: ciliary filter feeding and bio-fluid mechanics - present understanding and unsolved problems. Limnol Oceanogr 46(4): in press

Riisgård HU, Møhlenberg F (1979) An improved automatic recording apparatus for determining the filtration rate of Mytilus edulis as a function of size and algal concentration. Mar Biol 52:61-67

Riisgård HU, Randløv A (1981) Energy budgets, growth and filtration rates in Mytilus edulis at different algal concentrations. Mar Biol 61:227-234

Wildish DJ, Miyares MP (1990) Filtration rate of blue mussels as a function of flow velocity: preliminary experiments. J Exp Mar Biol Ecol 142:213-219

Wildish DJ, Saulnier AM (1993) Hydrodynamic control of filtration in Placopecten magellanicus. J Exp Mar Biol Ecol 174:65-82 